Int. J. Agril. Res. Innov. Tech. 10(2): 47-53, December 2020 Available online at https://ijarit.webs.com DOI: https://doi.org/10.3329/ijarit.v10i2.51576 https://www.banglajol.info/index.php/IJARIT

\title{
Investigating the risk and resilience of flash flood in Sunamgonj haor region of Bangladesh
}

\author{
M.R. Islam¹, M.A.H. Babu' ${ }^{1}$ M.J. Uddin², M.L. Khatun² and M.S. Islam²* \\ Received 30 June 2020, Revised 6 November 2020, Accepted 24 December 2020, Published online 31 December 2020
}

\begin{abstract}
A B S T R A C T
Bangladesh faces various types of natural hazards from its birth due to geographical location and physiographic conditions. Flood is the most common event among them. Northeastern part of Bangladesh faces flash flood almost every year with large scale of damage. Tanguar haor, (a famous Ramsar site of Bangladesh) located in Tahirpur upazila of Sunamgonj district. This wetland adjacent area is the most vulnerable zone in terms of flash flood hazard. About more than $80 \%$, people are the direct victim of this hazard. The aim of this study was to assess the risk and resilience status of flash flood at community level. A risk and resilience assessment matrix leads to fulfill the assessment where only primary data were used. A comparative study between those statuses is computed based on Pearson correlation of co-efficient analysis that presents the difference of risk and resilience of the study area that helps to realize the emergence of flash flood risk reduction. The findings of this study will be a pathway for the policy makers, local administrators for the development of sustainable community level risk management, policy-making and its implementations.
\end{abstract}

Keywords: Flash flood, Risk and resilience, Vulnerability, Tahirpur upazila.

${ }^{1}$ Department of Geography and Environment, Jahangirnagar University, Savar, Dhaka-1342, Bangladesh.

${ }^{2}$ Department of Environmental Science and Resource Management, Mawlana Bhashani Science and Technology University, Tangail-1902, Bangladesh.

*Corresponding author's email: islammstazu@yahoo.com (M.S. Islam)

Cite this article as Islam, M.R., Babu, M.A.H., Uddin, M.J., Khatun, M.L. and Islam, M.S. 2020. Investigating the risk and resilience of flash flood in Sunamgonj haor region of Bangladesh. Int. J. Agril. Res. Innov. Tech. 10(2): 47-53. https://doi.org/10.3329/ijarit.v10i2.51576

\section{Introduction}

Bangladesh is one of the most flood prone countries in the world located in South Asia. Due to the unique geographical location and special geo-natural, features of Bangladesh, different types and levels of floods occur here every year (Mirza, 2011). In the last half a century, there have been six severe floods that have affected $50 \%$ of the total area of the country. Since the early sixties of the last century, the country has taken a variety of measures for flood management and has mixed experiences of success and failure (Poncelet et al., 2010). Flood is a relatively high flow of water that flows across the natural or artificial banks of a river. When the water crosses the shore and floods the surrounding plains, it usually causes misery to the people (Ahmed, 2005). Since floodplains are desirable and conducive to agriculture, it is important to control floods and ensure that their damage does not exceed the limits. Flood in Bangladesh are generally divided into four major categories. These are flash flood, river flood, rain fed flood and coastal flood (Brammer, 1990). Among them flash flood is the most common hazard in northeastern region of Bangladesh.

People of the haor area are in great risk due to flash flood. Remoteness, poverty and natural hazards are the major risk factors here. About $87 \%$ of haor people are poor and primary economic activities are their main way of livelihood (Sun et al., 2017). Flash flood affects this region any time from March to September (Hossain et al., 2017). Boro Dhan (rice), BRRI Dhan 28 and BRRI Dhan 29 are the major food crops cultivated in Tanguar Haor region. Some other crops such as chili (Capsicum annuum), onion (Allium cepa), garlic (Allium sativum), potato (Solanum tuberosum), bean (Phaseolus lunatus) and coriander (Coriandrum sativum) are also cultivated here (Kamal et al., 2018). Among those crops, Boro Dhan, BRRI Dhan 28 and BRRI Dhan 29 are harvested in April to May when early flash flood visited every year. Other crops are damaged mainly due to mid and late 
flash flood (Islam et al., 2010). Besides, their housing structure makes them more vulnerable in terms of flash flood. Majority of their settlements are made by clay, bamboo, chhon (thatched roof), wood etc. About $87.2 \%$ houses are kancha, $6.9 \%$ jhupri, 5.2\% semi-pacca and remaining only $0.7 \%$ pacca (BBS, 2011). Most of the flood prone areas of Bangladesh are too much vulnerable because of the poor settlement structure.

Government of Bangladesh implies several action plans to reduce the risk factors. Strategies like protection strategies, short as well as long-term action plan are the main phase (Khan and Rahman, 2007). Protection strategies are the structural management such as embankments, flood shelter, flood proofing etc. Otherwise, some other actions like flood warning, changes of settlement structure, shifting of agriculture etc. All these helps to reduce risk of flash flood proportionately (Islam et al., 2010; Khan and Haque, 2010). Maximum number of haor people are not solvent, their economy is only haor based. That is why government should focus on them so that they can able to live a life with basic facilities (Khan and Rahman, 2007). The objectives of the study were to assess the flash flood risk status of local community; to analyze the resilience status, and to compare between flash flood risk and resilience status in the study area. This study will be a future guideline for the local community, policy makers and local administrators for the development of disaster risk reduction framework and relevant policymaking.

\section{Materials and Methods}

\section{Study area}

Tahirpur upazila is located in northeastern part of Bangladesh under Sunamgonj district. Tahirpur came into upazila in 1983. This upazila was named after the name of Tahir Ali Shah who was a religious preacher. The total area of this upazila is about $315.33 \mathrm{~km}^{2}$. Tahirpur upazila is located between $25^{\circ} \mathrm{O1}^{\prime}$ north latitude to $25^{\circ} 12^{\prime}$ north latitude and $91^{\circ} \mathrm{O2}^{\prime}$ east longitude to $91^{0}{ }^{1} 9^{\prime}$ east longitude. It is surrounded by Dharmapasha upazila in the west, Bishwambarpur in the east, Jamalganj in the south and India in the north (Fig. 1). Tahirpur upazila contains about 22000 households, with a total population of about 155188 (Banglapedia, 2014). Linguistically minors such as Garo and Hajong belong to this upazila.

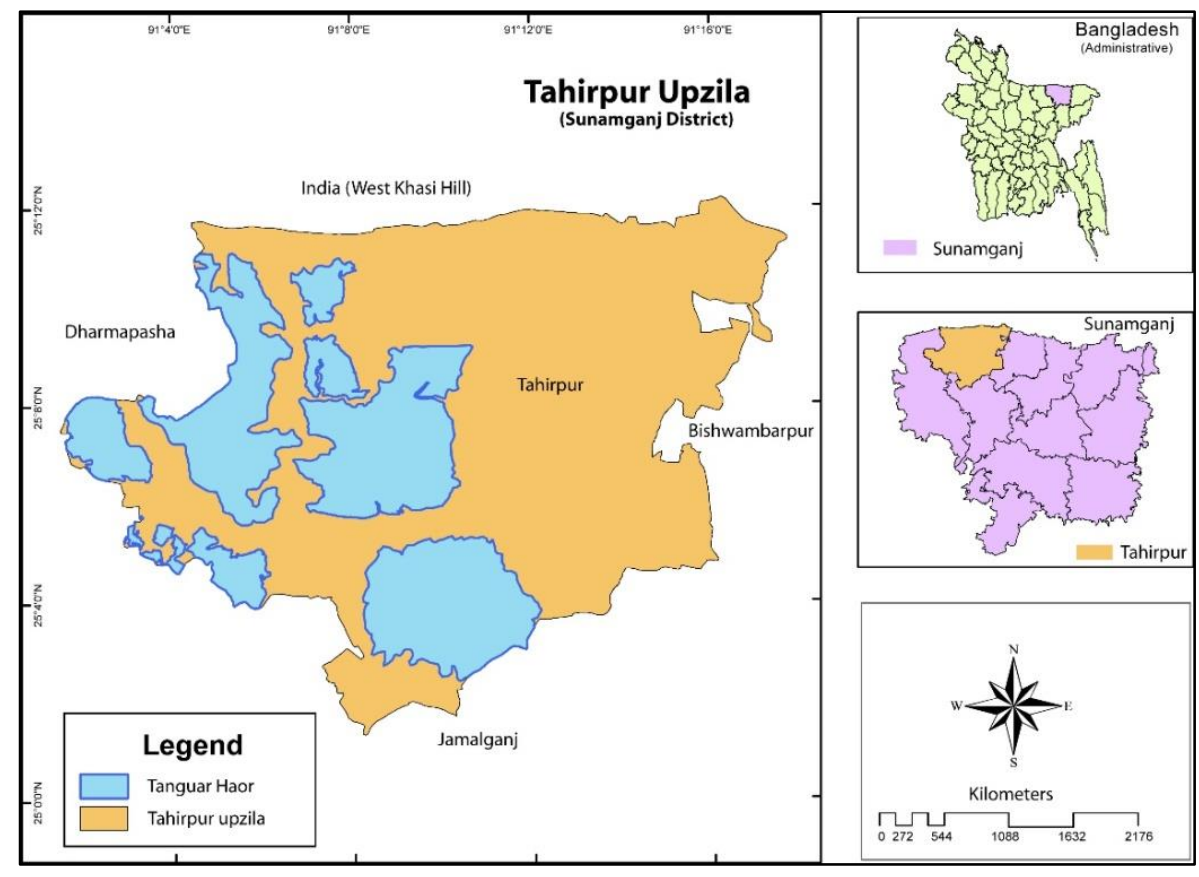

Fig. 1. Map showing the geographical location of the study area in Tahirpur upazila of Sunamgonj.

\section{Study process}

Data sources

To achieve the aim and objectives of this study both primary and secondary data have been used. The assessment of flash flood risk and resilience status of the study area were accomplished based on the data collected from primary sources, where local people of the study area were the unit of measurement. Primary data were- flash flood probability, flash flood vulnerability indicators, and indicators of resilience and the result of risk and resilience assessment. To construct the framework of this study and justify the flood vulnerability secondary data have been used as literature review of different books, journals, thesis papers and flood recorded data by Flood Forecasting warning center of the study area. 


\section{Data collection}

In order to realize study objectives primary data were collected based on both quantitative and qualitative approaches. Primary data have been collected through Field Observation, FGD (Focused Group Discussion), Questionnaire survey and Interview. These techniques were applied on the local people of the study area to assess the flash flood risk and resilience status using the risk assessment matrix and resilience assessment matrix. A risk assessment matrix is a matrix that assesses the risk using the hazard probability and vulnerability (Risk $=$ Hazard probability $\times$ Vulnerability). Flash flood probability was determined based on the frequency of this event in the study area according to the opinion of local people. Flash flood vulnerability indicators were identified through FGD (Per Union one FGD) based on the priority of respondents. A resilience assessment matrix is a matrix that assesses the resilience status using hazard probability and resilience status (Resilience $=$ Hazard probability $\times$ Resilience). Flash flood resilience indicators were marked through FGD based on the precedence of the respondent. Here, the more the flash flood probability and the more the vulnerability indicators, the more the flash flood risk. In addition, the less the flash flood probability and the more resilience indicators, the more the flash flood resilience. To collect this data, this study was used a simple random sampling method.

Sample size was calculated from the following equation (1).

Sample Size $=\frac{z^{2} \cdot p(1-p) / e^{2}}{1+\left(z^{2} \cdot p \frac{(1-p)}{e^{2} N}\right)}$

Where,

$\mathrm{N}=$ Population Size, $\mathrm{p}=$ the estimation of the proportion, $e=$ Margin of Error, $\mathrm{z}=\mathrm{z}$-score

Confidence Level $=80 \%$ and Margin of Error $=10 \%$

\section{Data analysis}

The raw data were processed through general percentage study using MS Excel, where the total collection is divided into four categories (For risk and resilience assessment such as extreme, high, moderate and low). Based on this risk status a zoning map was constructed using ArcMap. The relationship between risk and resilience status were accessed through Karl Pearson's Coefficient of Correlation method.

\section{Flash flood risk assessment}

Flash flood risk assessment is the mechanism to assess the risk status due to flash flood hazards. Tanguar haor adjacent areas face flash floods almost every year. This causes many damages, especially in the agriculture sector. Not only the agricultural sector but also their housing, communication, stored food, etc. faces damage too. Flash flood events occur frequently in Tahirpur upazila. However, not every people in the study area face flash flood hazards equally. The people, who live in low lying and haor adjacent areas, face this hazard more intensively. However, the others are not like them. This factor is the probability of flash flood hazard, which varies person to person, place to place in the study area. Otherwise, the damage rate also varies from person to person. For that reason, flash flood probability and vulnerability indicators have selected on a priority basis. Based on these observations flash flood risk assessment matrix was developed (Fig. 2). Flash flood risk was calculated in the study from the following equation (2).

Flash Flood Risk = Hazard (Flash flood probability) $\times$ Vulnerability .

\section{Flash flood probability}

Flash flood probability is the possibility of the occurrence of the flash flood that is not the same for all. In the study area, the variation seems in the same area based on some factors like floodproof housing, a settlement on high land, etc. That is why the probability of flash flood hazards categorized as five hierarchical stages. The flash flood probability is the primary mechanism to know the intensity of flash flood probability in the study area. People of Tahirpur upazila face flash flood in various level that depends on some criteria. Flash flood probabilities were determined through field survey (2018): i) Every year flash flood occurs severely; ii) It occurs every year but sometimes it is severe; iii) It occurs every year but not so severely; iv) It occurs after every few years (Generally after every 2-3 years) and v) It occurs once every ten years.

\section{Flash flood vulnerability}

Flash flood vulnerability is the possibility of harm due to flash flood. This also varies with area to area, person to person. In the study area, variation seems based on several statuses such as settlement status, economic status, dependency on agriculture, etc. Vulnerability indicators were marked as hierarchically based on the opinion of the people of the study area. Vulnerability indicators of the flash flood were selected based on field survey (2018): i) There is agricultural land in haor and its adjacent low-lying areas; ii) Livelihood is completely depending on agricultural production \& fishing; iii) Settlements are situated haor adjacent lower elevated areas \& height is low; iv) Homesteads have made by mud and other raw materials and v) Day-wise income (Fisherman, Day labor), lack of Savings \& poor flood Adjustment knowledge. 


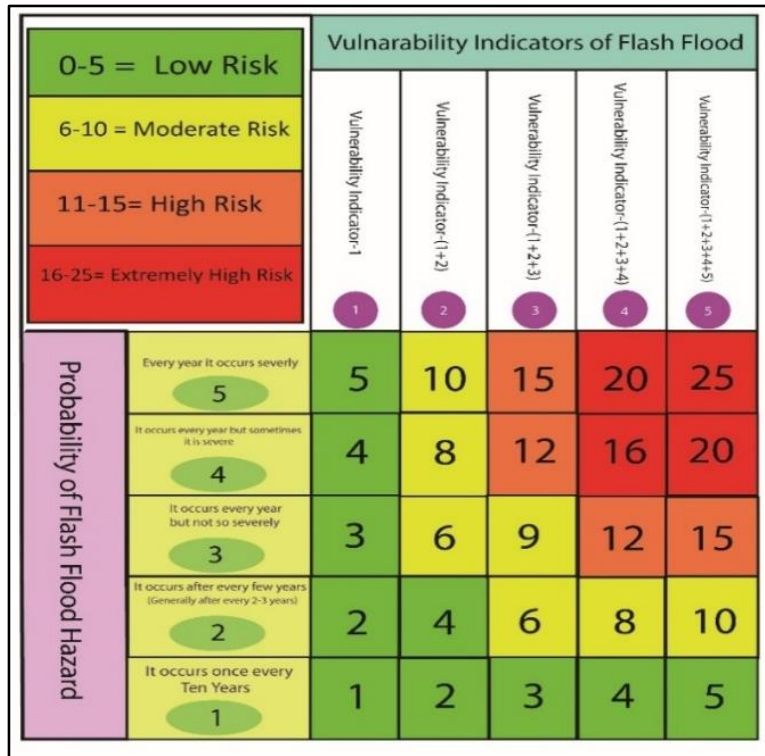

Fig. 2. Flash flood risk assessment matrix for the study area in Tahirpur upazila.

\section{Flash flood resilience assessment}

Flash flood is the most common natural hazard in Sunamgonj as well as Tahirpur upazila. People of this area face this type of hazard almost every year (Uddin et al., 2015). The flash flood affects their settlement, agricultural production, communication system and everything every year. However, their resilience status against this hazard is not so strong. Because of their poor economic status and the geographic location, also reduce the resilience status. For example, Boro is the main agricultural products for local community (Rabby et al., 2011). They cultivate it in haor areas and this crop faces flash flood most of the time. Resilience is the ability to bounce back from adversity (McAllister, 2013). It is a necessary skill for coping with life's inevitable obstacles and one of the key ingredients to success. Learning to bounce back and to bounce forward (Martin, 2002). Resilience is about being adaptable. It is about being flexible (Norbiato et al., 2008). Flash flood resilience status is the mechanism to assess the flash flood tolerance capability both structural purposes and nonstructural purposes (Norbiato et al., 2008). Structural purposes indicate the adaptive capacity of the settlement and other infrastructure against flash flood, and the nonstructural indicates everything relevant with livelihood. Flash flood resilience status was assessed from the following equation (3).

Flash flood resilience status $=$ Hazard probability $\times$ Resilience indicators.

Here, Hazard probability = the less the hazard probability the more the resilience probability. Resilience indicator $=$ the more the indicator the respondent have the more the resilience probability.

\section{Resilience indicators}

Flash flood resilience indicates the tolerance capability in terms of flash flood. This type of capability depends on people's surroundings and economic capability. Overall, the geographic condition of an area controls the resilience status. Resilience indicators of flash flood are identified through field survey (2018): i) settlements are protected by flood walls and plants (Hijal and Koros forest); ii) human settlements are made on the pile of soil and flood endures posts in low lying regions; iii) agricultural production remains after consumption for store and sell/ one or more economic man involved in secondary economic activities in urban areas; iv) there are savings accounts in bank/ women involved in microcredit/ economic solvency (family income more than 5000 per month) and v) rich in flood preparedness and adjustment knowledge/ trained volunteer/ ability to read early warning system. Based on flash flood probability and resilience indicators Flash Flood Resilience Matrix has developed (Fig. 3).

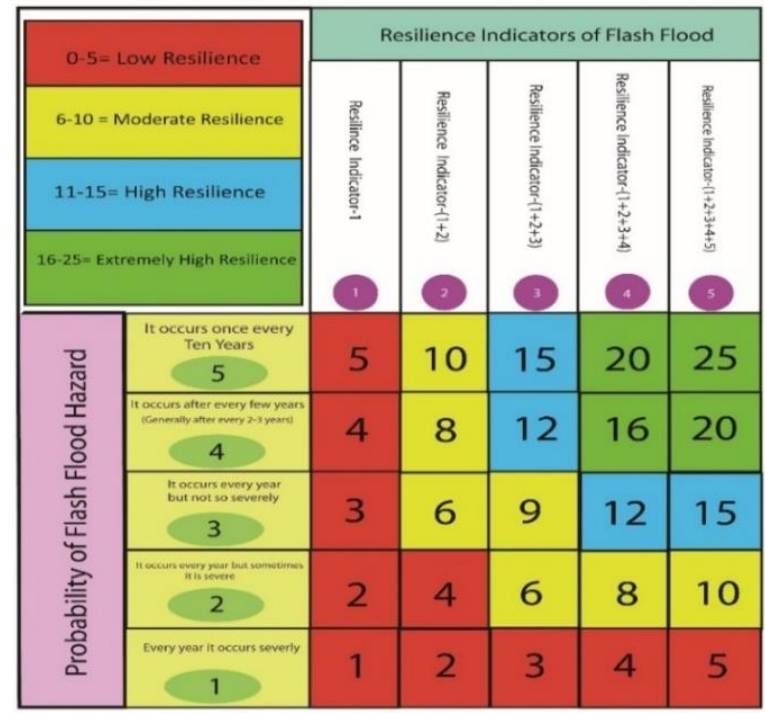

Fig. 3. Flash flood resilience assessmemt matrix for the study area in Tahirpur upazila.

\section{Results and Discussion}

Sunamgonj district is well known for one of the largest wetlands in the country and most spectacular place to visit named Tanguar haor. Tanguar haor is located at the foot of Meghalaya hill (Solayman et al., 2018). It is covering 9727 hectares, Tanguar haor in northeastern part of Bangladesh, adjacent to the Indian border, is part of a wetland of the Surma-Kushiyara rivers basins (Islam et al., 2010).

\section{Risk index of Tahirpur upazila}

The assessment of risk status of Tahirpur Upazila shows that the people of Uttar Sreepur and Dakshin Sreepur are in extremely high risk in terms of flash flood. About $75 \%$ people both of 
these unions are in extreme high risk. Otherwise, the people of Dakshin Badal, Uttar Badal and Badaghat are in high-risk zone and about more than $70 \%$, people are in this zone. Overall, Tahirpur sadar and Balijuri face moderate and low risk due to flash flood (Table 1). About 150000 people lives in this upazila. Among them more than half of the people are in high risk of flash flood, only $13.47 \%$ people are in low risk.

Table 1. Risk index for the study area in Tahirpur upazila (Source: Field Survey, 2018).

\begin{tabular}{lcccccc}
\hline Name of union & Population & SS & \multicolumn{4}{c}{ Nature of risk } \\
\cline { 4 - 7 } & & & Extremely high (\%) & High (\%) & Moderate (\%) & Low (\%) \\
\hline Uttar Sreepur & 33,457 & 83 & 77.01 & 12.05 & 4.92 & 6.02 \\
Dakshin Sreepur & 16,605 & 43 & 74.42 & 11.63 & 9.30 & 4.65 \\
Dakshin Badal & 16,827 & 45 & 8.88 & 84.44 & 4.44 & 2.21 \\
Uttar Badal & $\mathbf{2 5 , 5 1 4}$ & 61 & 11.21 & 76.49 & 9.24 & 3.06 \\
Badaghat & 33,454 & 82 & 14.21 & 69.77 & 13.91 & 2.21 \\
Tahirpur & 15,300 & 41 & 9.87 & 11.21 & 63.19 & 15.73 \\
Balijuri & $\mathbf{1 4 , 0 3 1}$ & 39 & 5.07 & 4.82 & 29.67 & 60.44 \\
\hline Tahirpur upazila & $\mathbf{1 , 5 5 , 1 8 8}$ & 394 & $\mathbf{2 8 . 6 7}$ & 38.63 & 19.23 & 13.47 \\
\hline
\end{tabular}

Note: SS = Sample Size.

\section{Risk zoning map of Tahirpur upazila}

Risk zoning is the mechanism that represents an area by dividing it based on their risk status. Risk zoning usually presented as map. The risk-zoning map usually important for disaster planning. Fig. 3 represents the several risk zone of Tahirpur upazila in terms of flash flood. According to this representation, Uttar Sreepur and Dakshin Sreepur unions are in extreme risk zone where only Balijuri union is in low risk zone. Dakshin Badal, Uttar Badal, Badaghat unions are in highrisk zone and only Tahirpur union is I moderate level. This presentation clearly shows that there flash risks are varies from union to union (Fig.3).

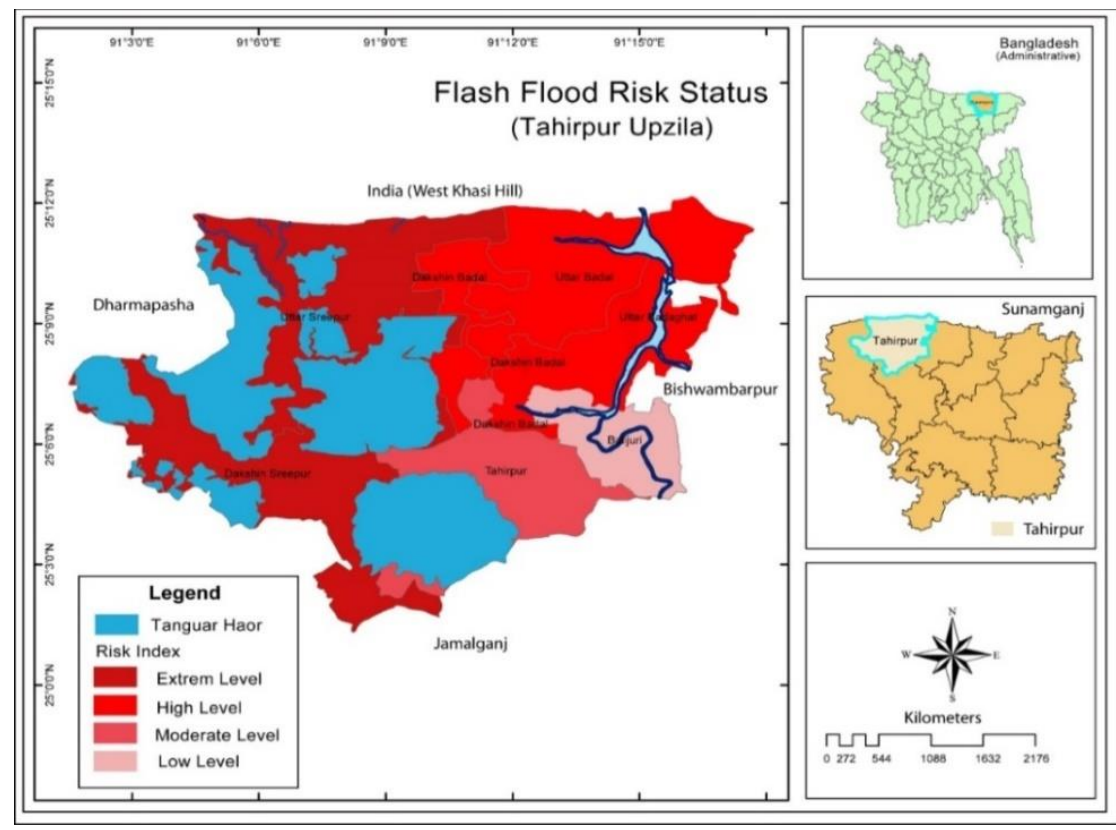

Fig. 4. Flash flood risk status of the study area in Tahirpur upazila.

\section{Risk index of Tahirpur upazila}

The resilience assessment shows that the highrisk zone people resilience status is poor. Unions of Tahirpur as Uttar Sreepur and Dakshin Sreepur are in extreme high risk but their resilience is too low. Unions are in high-risk zone resilience status is not as high as need. About $62 \%$ people of these unions are in low resilience. Tahirpur sadar and Balijuri union shows different status in resilience question. However, the overall resilience status of Tahirpur upazila is not satisfied in terms of flash flood risk status of this upazila. Because of this upazila, more than $66 \%$ people are in extreme and high risk where their extreme and high resilience proportion is only $24.61 \%$. This shows a huge gap and that is why they face a great harm due to flash flood almost every year (Table 2). 
Table 2. Resilience index of the study area in Tahirpur upazila (Source: Field Survey, 2018).

\begin{tabular}{lcccccc}
\hline \multirow{2}{*}{ Name of union } & Population & SS & \multicolumn{4}{c}{ Nature of resilience } \\
\cline { 3 - 7 } & & & Extremely high (\%) & High (\%) & Moderate (\%) & Low (\%) \\
\hline Uttar Sreepur & 33,457 & 83 & 10.84 & 18.07 & 14.45 & 71.08 \\
Dakshin Sreepur & 16,605 & 43 & 4.65 & 6.98 & 16.27 & 72.09 \\
Dakshin Badal & $\mathbf{1 6 , 8 2 7}$ & 45 & 13.33 & 8.89 & 15.56 & 62.22 \\
Uttar Badal & 25,514 & 61 & 4.92 & 8.20 & 22.95 & 63.93 \\
Badaghat & 33,454 & 82 & 9.76 & 6.09 & 14.63 & 69.51 \\
Tahirpur & 15,300 & 41 & 14.63 & 26.83 & 39.02 & 19.51 \\
Balijuri & $\mathbf{1 4 , 0 3 1}$ & 39 & 5.13 & 30.69 & 38.40 & 25.53 \\
\hline Tahirpur upazila & $\mathbf{1 , 5 5 , 1 8 8}$ & 394 & 9.04 & 15.11 & 23.05 & 52.80 \\
\hline
\end{tabular}

Note: SS = Sample Size.

\section{Comparative analysis between flash flood risk and flash flood resilience}

Risk and resilience is relevant with one another. If resilience status is strong, this can reduce the harm from hazards. The comparison between risk and resilience status tells us, how much in danger a particular community are. Correlation analysis represents the relationship between two or more variables. A connection coefficient is a numerical proportion of some sort of relationship, which means a factual connection between two factors. The factors might be two segments of a given informational collection of perceptions, frequently called an example, or two segments of a multivariate arbitrary variable with a known circulation (SchlickSteiner et al., 2008).

Table 3. Pearson correlation coefficient between flash flood risk and resilience status.

\begin{tabular}{|c|c|c|c|}
\hline \multicolumn{4}{|c|}{ Correlations } \\
\hline & & Risk status & Resilience status \\
\hline \multirow[t]{3}{*}{ Risk status } & Pearson correlation & 1 & $-0.819^{*}$ \\
\hline & Significance (2-tailed) & & 0.024 \\
\hline & $\mathrm{N}$ & 7 & 7 \\
\hline \multirow[t]{3}{*}{ Resilience status } & Pearson correlation & $-0.819^{*}$ & 1 \\
\hline & Significance (2-tailed) & 0.024 & \\
\hline & $\mathrm{N}$ & 7 & 7 \\
\hline
\end{tabular}

The correlation indicates a significant negative relationship $(r=-0.819, p<0.05)$ between risk and resilience in the study area (Table 3). For proper risk management, this type of relationship is not satisfactory. The study provides a clear indication that a wide range of risk reduction practices is required to improve the condition of flash flood in the study area.

\section{Conclusions}

Haor people are poor and vulnerable. They are mostly deprived, distressed and destitute. Although there was no dearth of prescription from the government and policy makers, haor people always remained excluded from the mainstream. Flash flood risk reduction capability of Tahirpur upazila mainly depends on Governmental actions. Government undertakes most of the actions. Most important task for flash flood risk reduction is structural development and emergency response capability. Emergency response system is well active in Tahirpur upazila. Haor people mainly the aged person accumulated regular and specialist knowledge about the flash floods through previous observation and practical experience of their surroundings. Local tales and anecdotes related to floods abound and reveal how people live and interpret their landscape over time. Their accounts provide many interpretations of the history and nature of past flash floods. However, not all these afford are so helpful to reduce the risk of flash flood. Disaster risk reduction is a systematic function to identify, assessing and reducing the risk of disaster. Main objective of disaster risk reduction is to reduce socioeconomic vulnerabilities in consider with disaster risk as well as facing with the environmental and other hazards that influence them. Government of Bangladesh implies several action plans to reduce the risk factors. Strategies like protection strategies, short-term action plan and long-term action plan are the main phase. Protection strategies are the structural management such asembankments, flood shelter, flood proofing etc. Otherwise, some other actions like flood warning, changes of settlement structure, shifting of agriculture etc., which are help to reduce risk of flash flood proportionately in the study area.

\section{Acknowledgement}

The authors sincerely acknowledge the cooperation of the Department of Geography and Environment (Jahangirnagar University, Dhaka), and Department of Environmental Science and Resource Management (Mawlana Bhashani Science and Technology University, Tangail) for using their GIS lab facilities during the study period. 


\section{References}

Ahmed, A.U. 2005. Adaptation options for managing water related extreme events under climate change regime: Bangladesh perspectives. pp. 255-278. In: Climate Change and water Resources in South Asia, Balkema Press, Leiden.

Akhter, H., Mia, C. and Panna, S.A. 2018. Understanding the changes of the wetland ecosystem and its impact on the biodiversity of Tanguar haor in Sunamgonj, Bangladesh. Asian J. Environ. Ecol. 7(4): 111. https://doi.org/10.9734/AJEE/2018/45229

Banglapedia. 2014. National Encyclopedia of Bangladesh. Accessible at http://en.banglapedia.org/index.php?title=Tahir pur_upazila.

BBS. 2011. Community Report, Sunamgonj Zila. Statistics and Informatics Division, Ministry of Planning, Government of the People's Republic of Bangladesh. p. 56.

Brammer, H. 1990. Floods in Bangladesh: geographical background to the 1987 and 1988 floods. Geograph. J. 156(1): 12-22. https://doi.org/10.2307/635431

Hossain, M.S., Nayeem, A. and Majumder, A.K. 2017. Impact of flash flood on agriculture land in Tanguar haor basin. Int. J. Res. Environ. Sci. 3(4): 42-45.

https://doi.org/10.20431/2454-9444.0304007

Islam, A.S., Bala, S.K. and Haque, M.A. 2010. Flood inundation map of Bangladesh using MODIS time series images. J. Flood Risk Manage. 3(3): 210-222.

Kamal, A.M., Shamsudduha, M., Ahmed, B., Hassan, S.K., Islam, M.S., Kelman, I. and Fordham, M. 2018. Resilience to flash floods in wetland communities of northeastern Bangladesh. Int. J. Disaster Risk Reduc. 31: 478-488.

https://doi.org/10.1016/j.ijdrr.2018.06.011

Khan, M.R. and Rahman, M.A. 2007. Partnership approach to disaster management in Bangladesh: a critical policy assessment. Nat. Hazards. 41(2): 359-378.

https://doi.org/10.1007/s11069-006-9040-y

Khan, S.M.M.H. and Haque, C.E. 2010. Wetland resource management in Bangladesh: implications for marginalization and vulnerability of local harvesters. Environ. Hazards. 9(1): 54-73. https://doi.org/10.3763/ehaz.2010.SIo8

Martin, G.E. 2002. Resilience: The ability to bounce back from adversity. Auseinetter. 14(1): 3-4. https://doi.org/10.6028/NIST.TN.1795
McAllister, T. 2013. Developing guidelines and standards for disaster resilience of the built environment: a research needs assessment. Gaithersburg, MD: US Department of Commerce, National Institute of Standards and Technology. pp. 1-142.

https://doi.org/10.6028/NIST.TN.1795

Mirza, M.M.Q. 2011. Climate change, flooding in South Asia and implications. Reg. Environ. Change. 11(1): 95-107.

Norbiato, D., Borga, M., DegliEsposti, S., Gaume, E. and Anquetin, S. 2008. Flash flood warning based on rainfall thresholds and soil moisture conditions: an assessment for gauged and un-gauged basins. $J$. Hydrol. 362(3-4): 274-290.

https://doi.org/10.1016/j.jhydrol.2008.08.023

Poncelet, A., Gemenne, F., Martiniello, M. and Bousetta, H. 2010. A country made for disasters: environmental vulnerability and forced migration in Bangladesh. pp. 211222. In: Environment, forced migration and social vulnerability. Springer, Berlin, Heidelberg.

Rabby, T.G., Alam, G.M., Mishra, P.K., Hoque, K.E. and Nair, S. 2011. Different economic and policy perspectives in micro population for sustainable development: a study of the haor livelihood in Bangladesh. African $J$. Busi. Manage. 5(6): 2475-2492.

SchlickSteiner, B.C., Steiner, F.M. and Pautasso, M. 2008. Ants and people: a test of two mechanisms potentially responsible for the large-scale human population-biodiversity correlation for Formicidae in Europe. $J$. Biogeography. 35(12): 2195-2206.

https://doi.org/10.1111/j.1365-2699.2008.01968.x

Solayman, H.M., Baten, M.A. and Khan, M.B. 2018. Status and economic valuation of ecosystem services of Tanguar haor: a wetland of Bangladesh. J. Bangladesh Agril. Univ. 16(2): 237-243.

https://doi.org/10.3329/jbau.v16i2.37968

Sun, C., Zhen, L. and Miah, M.G. 2017. Comparison of the ecosystem services provided by China's Poyang lake wetland and Bangladesh's Tanguar haor wetland. Ecosyst. Serv. 26: 411-421. https://doi.org/10.1016/j.ecoser.2017.02.010

Uddin, M.R., Miah, M.G.U., Afrad, M.S.I., Mehraj, H. and Mandal, M.S.H. 2015. Land use change and its impact on ecosystem services, livelihood in Tanguar haor wetland of Bangladesh. Sci. Agric. 12: 78-88.

https://doi.org/10.15192/PSCP.SA.2015.12.2.7888 